\title{
Effects of freshwater flow extremes on intertidal biota of a wet-dry tropical estuary
}

\author{
M. Duggan ${ }^{1, *}$, R. M. Connolly ${ }^{2}$, M. Whittle ${ }^{3}$, G. Curwen $^{1}$, M. A. Burford ${ }^{1}$ \\ ${ }^{1}$ Australian Rivers Institute, Griffith University, Nathan, Queensland 4111, Australia \\ ${ }^{2}$ Australian Rivers Institute - Coast \& Estuaries, and School of Environment, Griffith University, Gold Coast, \\ Queensland 4222, Australia \\ ${ }^{3}$ BioFouling Solutions, 244 Summerleas Rd, Kingston, Tasmania 7050, Australia
}

\begin{abstract}
Freshwater flow into estuaries during periods of high rainfall is considered to enhance the biomass of primary producers, with positive effects propagating to higher trophic groups. We examined the effect of flow on chlorophyll a (chl a) concentrations and meiofaunal abundance on the intertidal mudflats in a wet-dry tropical estuary in the Norman River, northern Australia. Meiofaunal density and sediment chl a concentrations (microphytobenthos) were significantly reduced during 2 consecutive wet season floods (the first, a major flood; the second, minor). Additionally, a short-term study of primary productivity on the mudflats during the minor flood measured rates below detection limits. The effects of salinity and burial by sediment on chl a concentrations and meiofaunal abundance were examined experimentally. Both the sudden and prolonged changes in salinity and sediment movement, and subsequent sedimentation as a result of wet season floods were the likely causes of the reduced meiofaunal density, chl a concentrations and benthic primary production. In the short term, large floods in the wet-dry tropics appear to act more as a disturbance event than a subsidy for benthic estuarine biota, and any positive effects of the flood may not occur until flooding eases. Additionally, we propose that there is a transitional period between the typical wet and dry seasons in the wet-dry tropics, during which flood waters are dissipating and the initial impact of the flood has abated, and there are positive effects on meiofauna and microphytobenthos biomass.
\end{abstract}

KEY WORDS: Meiofauna $\cdot$ Nematode $\cdot$ Copepod $\cdot$ Microphytobenthos $\cdot$ Monsoon $\cdot$ Algae $\cdot$ Benthic Resale or republication not permitted without written consent of the publisher

\section{INTRODUCTION}

Estuaries are highly productive coastal systems valued for their ecosystem services, which include providing habitat and breeding areas for birds and aquatic fauna, cycling nutrients and trapping sediment (Dürr et al. 2011, Milliman \& Farnsworth 2011). Estuarine function is strongly connected to adjacent freshwater, marine and terrestrial systems, and estuarine biota can be considered physiologically adapted to the variable nature of estuaries (Elliott \& Whitfield 2011). For instance, several studies directly relate freshwater flow to fishery catches of estuarine- dependent species, with either positive or negative relationships (Sobrino et al. 2002, Robins et al. 2005, Gillson 2011). Freshwater inflows to estuaries serve a variety of important functions, including prevention and alleviation of hypersaline conditions, creation of important habitat, as well as downstream delivery of sediment and nutrients (Loneragan \& Bunn 1999, Alber 2002, Gillanders \& Kingsford 2002, Kim \& Montagna 2009, Gillson 2011).

The role of freshwater flow in estuarine function and productivity is particularly important in the wet-dry tropics, where freshwater flow is both highly seasonal and highly variable, and reproduction, 
migration and growth of biota are adapted to this strong seasonality (Bunn \& Arthington 2002, Robins et al. 2005, Elliott \& Whitfield 2011). The wet-dry tropics cover northern Australia, parts of Indo-China, India, central Africa, Central and South America (Peel et al. 2007, Warfe et al. 2011). Unlike many similar systems in India and Africa, most rivers in the wet-dry tropics of northern Australia possess natural flow regimes as well as low catchment development, and are classified as near pristine (National Land and Water Resources Audit 2002, see Pusey 2011). In the face of planned water resource development in northern Australia, which will regulate and possibly reduce flooding, an understanding of the interactions between estuarine biota and freshwater flow regime in these rivers is essential.

Microphytobenthos (MPB) and meiofauna are useful for studying the impact of freshwater flow regimes on estuarine productivity and function because they respond quickly to changes in their environment with little or no lag effect, they have a limited ability to leave the estuary during periods of increased flow, are relatively easy to sample and highly abundant in estuarine sediments (Livingston 1997, Kennedy \& Jacoby 1999, Grego et al. 2009).

Meiofauna have frequently been used to study the change in aquatic species diversity along a salinity gradient from freshwater to marine (Remane \& Schlieper 1971, Giberto et al. 2007, Whitfield et al. 2012). They have also been used in disturbance studies to characterise the impact of various pollutants along a gradient within rivers and estuaries, as well as through time (Moreno et al. 2008, AmiardTriquet \& Rainbow 2009, Santos et al. 2009). Meiofauna and MPB are also important components of estuarine food webs, providing a major food source for higher trophic groups, and linking benthic and pelagic food webs (Wassenberg \& Hill 1993, Nozais et al. 2005, Kromkamp et al. 2006). MPB can contribute more primary production to an estuary than saltmarshes, seagrasses or mangroves (Kennish 1990), and MPB biomass is often greater than that of phytoplankton (MacIntyre et al. 1996, Burford et al. 2008). Additionally, meiofauna on intertidal mudflats have been found to contribute up to one third of the production within the primary consumer trophic level of estuaries (Coull 1999, Barros et al. 2008, Giere 2009).

Much of the research on the impact of freshwater flow on estuarine MPB and meiofauna has been done in temperate systems, and it is largely from these that theories of flow effects have been developed. Tropical systems are less well studied. In the wet-dry trop- ics, where patterns of freshwater flow are extreme, very little research exists examining the effects of freshwater flow on estuarine productivity. This study examines the response of MBP (and settled phytoplankton cells) and meiofauna on intertidal mudflats to seasonal patterns of freshwater flow in the Norman River Estuary, and tests the theory that periods of increased freshwater flow to the estuarine ecosystem increases the biomass of primary producers, with flow-on effects to higher trophic groups. Key physical changes in the estuary associated with seasonal changes in freshwater flow are identified, including distinct periods of change within the estuary before, during and after 2 different flood events.

\section{MATERIALS AND METHODS}

\section{The Norman River Estuary}

Located in the wet-dry tropics of northern Australia, the Norman River $\left(17.463^{\circ} \mathrm{S}, 140.82^{\circ} \mathrm{E}\right)$ is a dryland river system (Fig. 1). The climate is characterised by high temperatures and humidity (mean annual min. temperature $=20^{\circ} \mathrm{C}$, mean annual max. temperature $31^{\circ} \mathrm{C}$, relative humidity $=60 \%$; Australian Bureau of Meteorology, www.bom.gov.au), with distinctly monsoonal rainfall resulting in alternating patterns of summer wet (December to March) and winter dry periods (April to November). During the dry season, no freshwater flow enters the estuary and it becomes hypersaline, whereas during the wet season, there is often an extended period of widespread overbank flooding. The Norman River Estuary is a tide-dominated estuary, with a diurnal tidal cycle in the range of 3 to $4 \mathrm{~m}$. Extensive intertidal mudflats dominate the channel area and the few tidal creeks of the estuary. Per unit area, mangroves are estimated to have the largest pool of carbon in the Norman River Estuary (5 $118796 \mathrm{mg} \mathrm{C} \mathrm{m}^{-2}$ ), followed by intertidal sediment excluding MPB and meiofauna (9810 $\mathrm{mg} \mathrm{C} \mathrm{m}^{-2}$ ), and then intertidal MPB (2167 $\mathrm{mg} \mathrm{C} \mathrm{m}^{-2}$ ), phytoplankton (720 $\mathrm{mg} \mathrm{C} \mathrm{m}^{-2}$ ), juvenile penaeid prawns $\left(72 \mathrm{mg} \mathrm{C} \mathrm{m}{ }^{-2}\right)$ and meiofauna (<6 $\mathrm{mg} \mathrm{C} \mathrm{m}^{-2}$ ) (Duggan 2012).

\section{Sampling regime}

The intertidal mudflats of 2 channel sites (Fig. 1; Sites 1 and 3) and 3 creek sites (Fig. 1; Sites 2, 4 and 5) within the Norman River Estuary were sampled at low tide for chlorophyll a ( $\mathrm{chl}$ a) concentrations (as a 


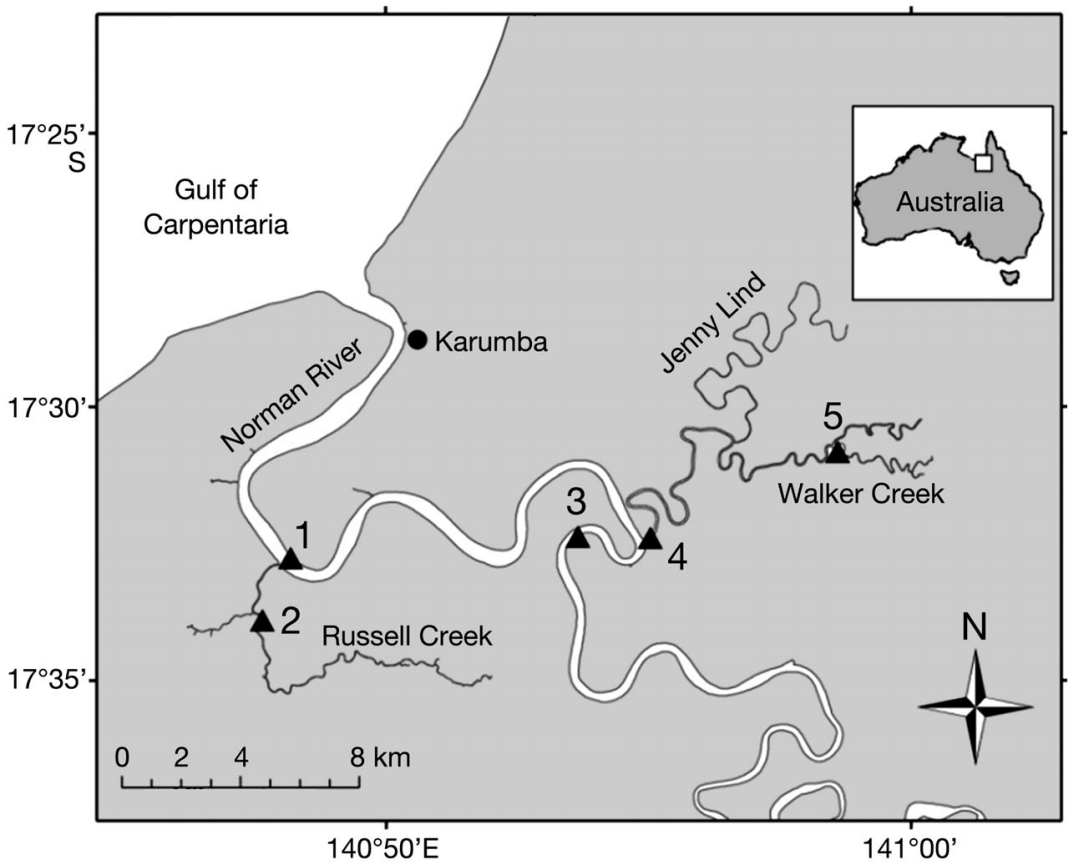

Fig. 1. Norman River Estuary, Australia, showing intertidal mudflat sampling sites (solid triangles, Sites 1 to 5)

measure of MPB biomass and settled phytoplankton cells) and meiofaunal abundance. Sites were sampled fortnightly from Oct 2008 to Mar 2009, and from Oct 2009 to Mar 2010, as well as in the first week of Jun 2009 and 2010. Secchi depth was recorded, and temperature, salinity, oxygen and $\mathrm{pH}$ were measured at the surface of adjacent water using a calibrated datalogger (Sonde) at the same time as sampling of the mudflats. In Nov 2009 (dry season) and Feb 2010 (wet season), sediment was collected from Sites 1, 3 and 4 for measurements of benthic oxygen fluxes, to determine benthic primary productivity.

Three replicate sediment surface cores of $1 \mathrm{~cm}$ depth and $2.4 \mathrm{~cm}$ diameter were collected fortnightly from the low intertidal area of each site for analysis of chl a. Core samples were taken from a boat, to avoid the occupational hazard of crocodiles. Samples were immediately frozen in a standard freezer for transport to the laboratory, where they were stored at $-80^{\circ} \mathrm{C}$ prior to analysis. Chlorophyll was extracted in $100 \%$ acetone by sonicating for $1 \mathrm{~min}$ on ice (Branson Sonifier 450) and measured spectrophotometrically with and without addition of hydrochloric acid ( 2 drops of $2 \mathrm{~N} \mathrm{HCl}$ ). The acid factor was calculated and, if the resulting value was $\geq 1.7$, the trichloromatic method of Jeffrey \& Humphrey (1975) was used to calculate chl a. If the acid factor value was $<1.7$, the monochromatic method of Lorenzen (1967) was used.
Three replicate sediment cores of $2 \mathrm{~cm}$ depth and $3 \mathrm{~cm}$ diameter were collected from the low intertidal area for meiofaunal abundance using a modified $50 \mathrm{ml}$ syringe attached to a pole. For preservation of contractile and soft bodied meiofauna, animals were anesthetized prior to fixation as recommended by Giere (2009), using $7 \%$ magnesium chloride hexahydrate with seawater. After $10 \mathrm{~min}$, Sörensen's Buffer (10\% phosphate-buffered formalin in seawater) was added to the sediment (Giere 2009). In the laboratory, samples were transferred to $70 \%$ ethanol dyed with Rose Bengal for storage. Meiofauna were extracted from the sediment using a modified version of the Ludox flotation method (Giere 2009). Each sample was divided into 4 tubes with approximately a $5 \mathrm{ml}$ volume of sediment in each, then Ludox® (AM-30 colloidal silica, 30 wt \% suspension in water) was added. Tubes were shaken and centrifuged (Eppendorf Centrifuge $5810 \mathrm{R}$ ) for $10 \mathrm{~min}$ at $1000 \mathrm{rpm}$. The supernatant was filtered through a $5 \mu \mathrm{m}$ mesh, and retained meiofauna were identified using a dissecting microscope. Nematodes and copepods dominated the meiofauna to the point where they were often the only taxa present; all statistical analyses were thus on these 2 taxa. At regular intervals, the remaining sediment was examined to ensure that meiofauna were not missed. This method resulted in $92 \%$ of copepods and $97 \%$ of nematodes extracted from the sediment.

\section{Oxygen flux measurements}

Replicate cores of sediment from Sites 1, 3 and 4 (Fig. 1) were collected in Nov 2009 (dry season) and Feb 2010 (during the minor flood) to compare primary productivity (as measured by oxygen fluxes) of the mudflats before and during flood conditions. Sediment to a depth of $5 \mathrm{~cm}$ was collected from intertidal mudflats prior to 08:00 h using clear Perspex cores $(4.5 \mathrm{~cm}$ diam.). Water collected at the site of sediment collections was added on top sediment in each core $(87 \mathrm{ml})$ to ensure there were no air bubbles, and cores were sealed with clear lids. Four cores from each site were completely covered in black fabric to remove light (dark treatment), and another 4 cores from each site remained uncovered in full sunlight (light treatment) 
throughout the day (from approx. 08:00 until 18:00 h). Cores were incubated in continuously flowing estuarine water to maintain ambient water temperature. Cores were equilibrated for $1 \mathrm{~h}$, then dissolved oxygen and temperature in the overlying water were recorded hourly for $5 \mathrm{~h}$ until late in the evening using a Presens ${ }^{\circledR}$ fiber-optic oxygen sensor (FIBOX) and oxygen-sensitive optode patches glued to the inside wall of each core (Presens). In this short-term study, an incubation time of approximately $5 \mathrm{~h}$ with regular measurements during this period was found to be sufficient for a substantial change in oxygen concentrations, and dissolved oxygen fluxes were calculated from the linear regression of dissolved oxygen measurements as a function of incubation time, standardised to area and converted to carbon dioxide fluxes.

Non-biological changes in dissolved oxygen were measured using controls with only deionised water and no sediment, and accounted for when calculating dissolved oxygen fluxes. A preliminary study was also conducted which compared dissolved oxygen fluxes measured in cores at night with cores that were covered in black fabric during the day. This was done to ensure that simulating night/dark conditions by covering cores in black fabric represented night time respiration.

\section{Effect of salinity}

Twelve cores of mudflat sediment from site 1 (Fig. 1) were collected as outlined in the previous subsection to examine the impact of reduced salinity on benthic oxygen fluxes. Sediment was collected for experiments in the 2009 dry season (Nov), when mean salinity in the estuary was 34.2 (SD 3.7). There were 3 salinity treatments: zero (freshwater), 25 (intermediate) and 35 (marine), and each treatment had 4 replicates. Deionised water was added to the top of each core for the freshwater treatment. Aquarium salt (Aquasonic Ocean Nature) was mixed with deionised water to a salinity of 25 and 35 for the intermediate and marine salinity treatments, respectively, and added to cores. The salinity in the marine treatment matched ambient estuarine conditions at the time of the experiment. Cores were sealed and incubated as outlined in the previous subsection, and allowed to equilibrate for $1 \mathrm{~h}$ before dissolved oxygen and temperature in the overlying water were recorded hourly for $23 \mathrm{~h}$ using a Presens ${ }^{\circledR}$ oxygen sensor. Measurements were divided through time into light (day) and dark (night) measurements. Dissolved oxygen fluxes were calculated as above.

\section{Salinity/burial experiment}

An experiment was conducted in Nov 2009 (dry season) to examine the response of microphytobenthos and meiofauna to 3 levels of sediment deposition: no burial, low burial $(1 \mathrm{~cm})$ and high burial $(3$ to $4 \mathrm{~cm}$ ), and to 2 different salinity conditions: freshwater salinity (0) and marine salinity (35). A factorial design was used for the 2 salinity and 3 burial treatments, resulting in a total of 6 treatment combinations with 4 replicates each.

Sediment for the experiment was collected from the low intertidal zone of Site 1 (Fig. 1) using clear Perspex cores (6 $\mathrm{cm}$ diam.) with a rubber bung in the bottom of each core. Cores were incubated in running water to maintain ambient water temperatures, and left to equilibrate in ambient light and temperature conditions with no overlying water for approximately $12 \mathrm{~h}$ (the duration of low tide). Water and additional sediment (to replicate burial) were then mixed thoroughly and poured into each core in a factorial design according to the 3 burial and 2 salinity treatments outlined above. Sediment added to cores to imitate burial had been previously collected from intertidal mudflats during flooding, and kept frozen for the purpose of this experiment. Deionised water was used for freshwater treatments, and aquarium salt was added to deionised water to a salinity of 35 for marine treatments.

Cores were incubated for $7 \mathrm{~d}$ in continuously flowing estuarine water to maintain ambient water temperature, and subject to ambient light conditions (full sunlight during the day, no sunlight during the night). In the afternoon of Day 7, samples were collected from sediment added to cores to simulate burial before being scraped off, and cores $(2.4 \mathrm{~cm}$ diam.) of sediment were collected from the original (not overlying) sediment in each core. All samples were collected for chl a analysis and meiofaunal abundance estimates. Samples were collected to a depth of $1 \mathrm{~cm}$, and were processed using the same method already outlined for measuring chl a concentrations and meiofaunal abundance.

\section{Data analysis}

The effect of region within the estuary (Lower estuary: Sites 1 and 2; Upper estuary: Sites 3, 4 and 5) (Fig. 1) and season (dry season, wet season and transitional period) on salinity, chl a concentration, copepod and nematode densities were examined using 2-way between-groups ANOVA. These analyses were used 
Table 1. Mean (SD) salinity, temperature, $\mathrm{pH}$, dissolved oxygen (DO) and Secchi depth measured in water adjacent to the intertidal mudflat Sites 1 to 5, and mean (SD) chl $a$, chl $b$ and chl $c$ measured on intertidal mudflat Sites 1 to 5

\begin{tabular}{|c|c|c|c|c|c|c|}
\hline & \multicolumn{3}{|c|}{ Major flood } & \multirow{2}{*}{ Dry season } & \multirow{2}{*}{$\begin{array}{l}\text { Minor flood } \\
\text { Wet season }\end{array}$} & \multirow[b]{2}{*}{ Trans. period } \\
\hline & Dry season & Wet season & Trans. period & & & \\
\hline Salinity & $33.7(2.4)$ & $0.2(0.2)$ & $1.9(13.9)$ & $31.7(6.1)$ & $4.3(3.9)$ & $6.9(10.2)$ \\
\hline Temperature $\left({ }^{\circ} \mathrm{C}\right)$ & $30.3(1.1)$ & $29.6(2.6)$ & $27.3(3.2)$ & $31.1(2.1)$ & $29.5(1.9)$ & $29.6(3.2)$ \\
\hline $\mathrm{pH}$ & $7.9(0.2)$ & $7.3(0.4)$ & $7.6(0.7)$ & $7.8(0.1)$ & $7.6(0.4)$ & $7.7(0.1)$ \\
\hline $\mathrm{DO}\left(\mathrm{mg} \mathrm{l}^{-1}\right)$ & $4.2(0.48)$ & $6.1(0.9)$ & $3.8(2.3)$ & $5.9(1.3)$ & $5.0(0.6)$ & $4.5(1.3)$ \\
\hline Secchi depth (m) & $0.2(0.1)$ & $0.3(0.2)$ & $0.4(0.2)$ & $0.2(0.1)$ & $0.1(0.1)$ & $0.3(0.1)$ \\
\hline Chl a $\left(\mathrm{mg} \mathrm{m}^{-2}\right)$ & $31.8(11.1)$ & $12.4(6.5)$ & $66.8(49.2)$ & $57.4(26.9)$ & $33.3(14.2)$ & $58.5(18.7)$ \\
\hline Chl $b(\%)$ & $47.0(23.5)$ & $50.8(40.5)$ & $24.5(22.8)$ & $30.3(28.3)$ & $33.0(21.8)$ & $18.9(17.9)$ \\
\hline Chl $C(\%)$ & $61.6(21.0)$ & $44.7(34.7)$ & $33.6(30.3)$ & $34.3(14.1)$ & $39.2(27.8)$ & $19.9(22.1)$ \\
\hline Phaeopigments (\%) & $3.3(3.7)$ & $1.3(0.3)$ & $3.6(2.6)$ & $0.9(0.3)$ & $0.6(0.1)$ & $0.9(0.1)$ \\
\hline
\end{tabular}

to explore the extent of effects from floods of different magnitudes on these parameters. Comparisons between years were made using a $t$-test for salinity, $\operatorname{chl} a$ concentration, copepod and nematode densities. A partial correlation was used to explore the relationships between chl a concentration, salinity, temperature, nutrient and Secchi depth, while controlling for salinity. A one-way between-groups ANOVA with a Tukey post-hoc test was carried out on oxygen flux measurements made in both the dry and wet seasons for seasonal comparisons. The same test was carried out on oxygen flux experiments to examine differences between salinity treatments. Impacts of different levels of burial and different salinities on chl a concentrations in the salinity/burial experiment were analysed using a 2-way between-groups ANOVA. Checks of assumptions were performed for all tests, and where assumptions could not be achieved even with transformation, results were interpreted cautiously by using an adjusted alpha value of 0.01 .

\section{RESULTS}

\section{Major flood}

During the wet season associated with the major flood (Jan to Mar 2009), there was no exposure of the intertidal mudflat at low tide. Mean salinity for the estuary during the wet season was 0.2 (SD 0.2), which was significantly $(\mathrm{p}<0.001)$ lower than salinity in the previous dry season (mean 33.2; SD 1.8) (Table 1). The transitional period after the wet season started in late Mar 2009, and was still in effect in early Jun 2009. Mean salinity in the transitional period after the major flood was 12.0 (SD 14.0), which was significantly lower than the dry season pre-flood $(p<0.001)$ and significantly higher than during the wet season $(p<0.001)$ (Table 1). During the wet season, mean chl a concentration throughout the estuary was $13.0 \mathrm{mg} \mathrm{m}^{-2}$ (SD 3.7), which was significantly lower than the $32.5 \mathrm{mg} \mathrm{m}^{-2}$ (SD 14.1) measured in the preceding dry season $(\mathrm{p}<0.01)$, and was significantly lower than the $67.8 \mathrm{mg} \mathrm{m}^{-2}$ (SD 4.7) measured in the transitional period after the flood $(\mathrm{p}<0.01)$ (Fig. 2). Mean chl a concentrations measured in the transitional period after the major flood was significantly higher than concentrations measured in the dry season before the flood ( $<$ 0.001) (Fig. 2). In the first year of sampling (major flood), phaeopigments were a small proportion of chlorophyll measurements, ranging from 0.6 to $3.3 \%$ of the chl $a$, and did not vary seasonally (Table 1 ). Chl $b$, as a measure of green algae, was present in proportions ranging from 18.9 to $50.8 \%$ of $\mathrm{chl}$ a. There was no evidence of seasonal differences. Chl $c$, principally as a measure of diatoms, was present in proportions similar to $\mathrm{chl} b$ (19.9 to $61.6 \%$, relative to chl $a)$, and there was no evidence of seasonal differences.

Mean copepod density was 0.2 ind. $10 \mathrm{~cm}^{-2}$ (SD $0.1)$ during the major flood, which was significantly lower than the 1.5 ind. $10 \mathrm{~cm}^{-2}$ (SD 0.2) measured in the dry season before the flood ( $p<0.01)$ (Fig. 2). In the transitional period after the flood, mean copepod density was 0.9 ind. $10 \mathrm{~cm}^{-2}$ (SD 0.2), which was not significantly different to densities before or during the major flood ( $p>0.05$ ) (Fig. 3). During the major flood, mean nematode density was 3.0 ind. $10 \mathrm{~cm}^{-2}$ (SD 0.9), which was significantly lower than the 9.8 ind. $10 \mathrm{~cm}^{-2}$ (SD 1.4) measured before the flood $(\mathrm{p}<0.001)$ and the 8.2 ind. $10 \mathrm{~cm}^{-2}$ (SD 0.4$)$ measured in the transitional period after the flood $(\mathrm{p}<0.01)$ (Fig. 3). There were no significant differences in mean nematode density between the dry season before the flood and the transitional period after the flood ( $p>0.05$ ) (Fig. 3). 

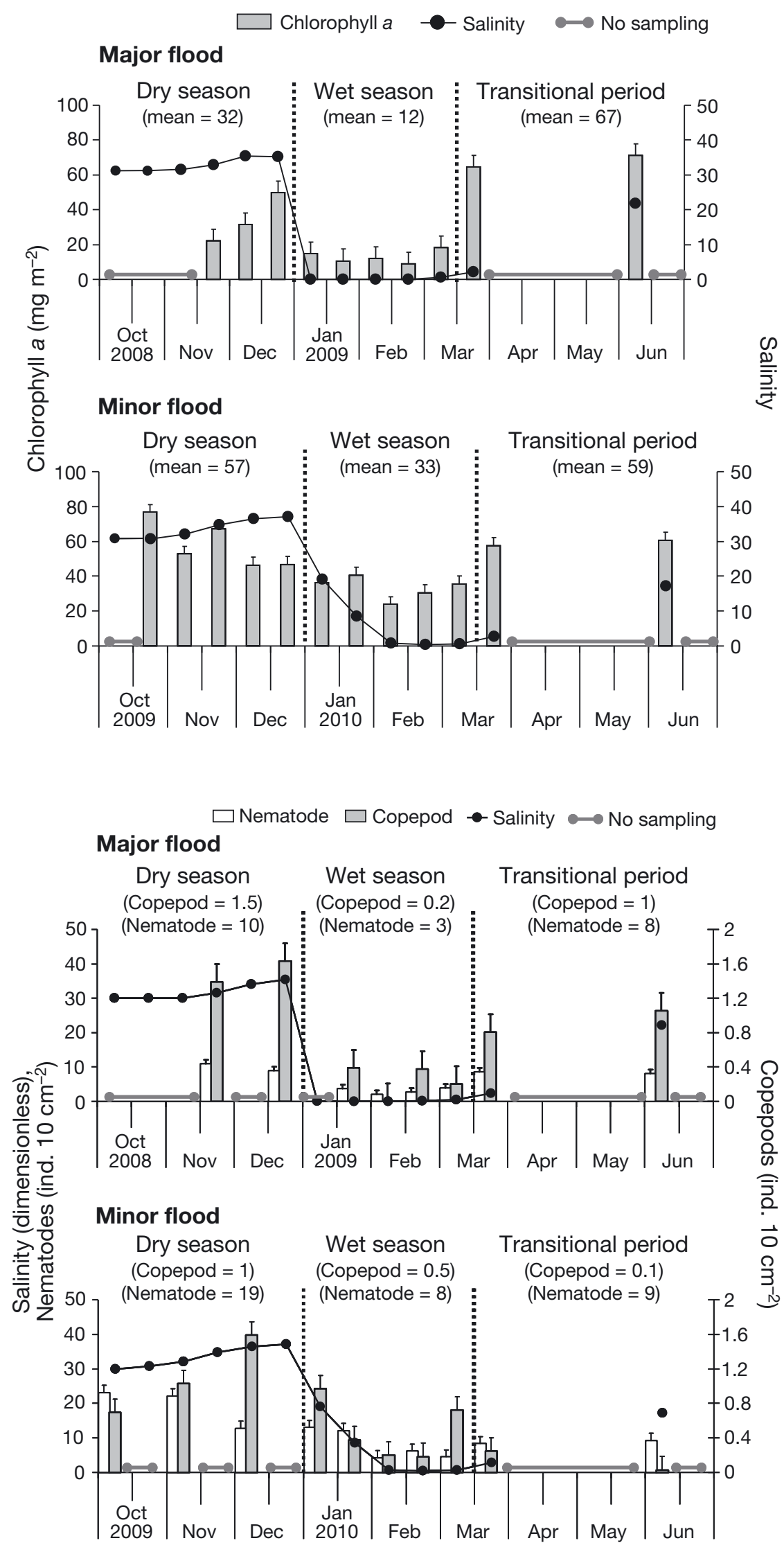

Fig. 2. Benthic chl a (mean, $\mathrm{SD}_{i} \mathrm{mg} \mathrm{m}^{-2}$ ) and salinity across all sites measured fortnightly from Nov 2008 to Mar 2009 and Jun 2009 (major flood), and Oct 2009 to Mar 2010 and Jun 2010 (minor flood). Values in parentheses are mean benthic chl a concentrations for the dry season, the wet season and the transitional period. No sampling was conducted outside of these months

\section{Minor flood}

During the wet season resulting from the minor flood, intertidal mudflats were exposed at low tide, but the extent of exposure was less than during the dry season. Mean salinity throughout the estuary during the minor flood (wet season) was 4.3 (SD 6.3 ), which was significantly ( $\mathrm{p}<$ 0.001 ) lower than salinity in the dry season before the minor flood (mean 31.79, SD 4.2; Table 1). Mean salinity in the transitional period after the minor flood was significantly lower than salinity before the flood $(\mathrm{p}<$ 0.001 ) at 7.0 (SD 9.7), and was not significantly different to during the flood ( $p>0.01$ ).

During the minor flood, mean chl a concentrations were $33.2 \mathrm{mg} \mathrm{m}^{-2}$ (SD 7.5), which was significantly lower than the $56.9 \mathrm{mg} \mathrm{m}^{-2}$ (SD 12.8) measured before the flood $(\mathrm{p}<0.001)$ (Fig. 2). Concentrations in the transitional period after the minor flood were $59.2 \mathrm{mg} \mathrm{m}^{-2}$ (SD 3.1), which was significantly higher than during the flood $(p<0.01)$, but were not signifi-

Fig. 3. Salinity, nematode and copepod density (mean, SD; ind. $10 \mathrm{~cm}^{-2}$ ) across all sites for the major flood (Nov 2008 to Mar 2009 and Jun 2009) and the minor flood (Oct 2009 to March 2010 and Jun 2010). Samples were collected monthly during the dry season, and fortnightly during the wet season. Values in parentheses are mean copepod and nematode densities for the dry season, the wet season and the transitional period. Note: salinity and nematode density displayed on primary $y$-axis (using the same scale); copepod density displayed on secondary $y$-axis 
cantly different before the flood ( $\mathrm{p}>0.05)$ (Fig. 2). During the second year of sampling (minor flood), phaeopigments were a small proportion of chlorophyll measurements (mean 0.4 [SD 0.2] $\mathrm{mg} \mathrm{m}^{-2}$ ) and both chl $b$ (mean 10.7 [SD 1.4] $\mathrm{mg} \mathrm{m}^{-2}$ ) and $\mathrm{chl} c$ (mean 13.0 [SD 3.3] $\mathrm{mg} \mathrm{m}^{-2}$ ) were detectable. Mean copepod densities before, during and after the minor flood were 1.1 (SD 0.4), 0.5 (SD 0.3) and 0.1 (SD 0.1) ind. $10 \mathrm{~cm}^{-2}$, respectively, and were not significantly different from each other ( $p>0.05)$ (Fig. 3). Mean nematode densities before, during and after the minor flood were 19.3 (SD 5.6), 7.9 (SD 4.2) and 8.7 (SD 0.6) ind. $10 \mathrm{~cm}^{-2}$, respectively, and again were not significantly different from each other $(p>0.05)$ (Fig. 3).

\section{Region comparison}

There was no significant difference in nematode or copepod density, or chl a concentration between the upper and lower estuary during the first dry season or the first wet season $(p>0.05)$. There was no significant difference in nematode density or chl a concentrations between the upper and lower estuary during the first transitional period ( $p>0.05)$, however, copepod density was significantly higher in the lower estuary $(p<0.05)$.

$\mathrm{Chl}$ a concentrations were significantly higher in the lower estuary $(p<0.005)$ during the second dry season, while there were no significant differences in nematode and copepod densities between regions $(p>0.05)$. During the second wet season (minor flood), copepod density was significantly higher in the lower estuary then the upper estuary $(p<0.001)$, and there were no significant differences in nematode density or chl a concentrations between regions ( $p>0.05)$. There were no significant differences in nematode or copepod density, or chl a concentrations between regions during the second transitional period $(p>0.05)$.

\section{Season comparison}

There was no significant difference in salinity, copepod or nematode densities between the first (2008) and second dry seasons (2009) ( $p>0.05$ ); however, chl a concentrations were significantly higher in the second dry season than the first $(p<$ 0.001). Chl a concentrations were also higher in the second wet season $(2010$, minor flood) than the first $(2009$, major flood) $(\mathrm{p}<0.001)$, as was salinity $(\mathrm{p}<0.01)$, and nematode density $(\mathrm{p}<0.01)$. Copepod density was not different between the first and second wet seasons $(p>0.05)$. There was no significant difference in salinity $(\mathrm{p}>0.05)$, chl $a$ concentrations $(p>0.05)$ or nematode densities $(p>0.05)$ between the transitional period after the major flood (2009) and the transitional period after the minor flood (2010). Copepod density was higher in the first transitional period than in the second $(p<0.05)$.

\section{Correlations between parameters}

There were positive correlations (albeit with low $\mathrm{r}$ values) between chl a concentrations and salinity $(\mathrm{r}=0.26, \mathrm{df}=216, \mathrm{p}<0.005)$, between copepod densities and salinity $(\mathrm{r}=0.40, \mathrm{df}=141, \mathrm{p}<0.005)$, and between nematode densities and salinity $(\mathrm{r}=$ $0.27, \mathrm{df}=207, \mathrm{p}<0.005)($ Table 2). There were positive partial correlations between chl a concentrations and temperature $(\mathrm{r}=0.23, \mathrm{df}=215, \mathrm{p}<$ $0.005)$, and between nematode density and chl $a$ concentration $(\mathrm{r}=0.25, \mathrm{df}=206, \mathrm{p}<0.005)$ while controlling for salinity, although the $\mathrm{r}$ values were also low (Table 2). The zero order correlation $(\mathrm{r}=$ 0.23 , and $r=0.30$, respectively) suggests that controlling for salinity had no effect on the strength of correlations between chl a concentration and temperature, or between nematode density and $\mathrm{chl} a$ concentrations.

Table 2. Normal Pearson product-moment correlation matrix between variables, with and without partitioning salinity from the analysis (above and below the diagonal, respectively). Values in bold are statistically significant $(2$-tailed, $\mathrm{p}<0.05)$

\begin{tabular}{|c|c|c|c|c|c|c|c|c|c|c|c|c|c|c|c|}
\hline & \multicolumn{3}{|c|}{ - Benthic chl $a-$} & \multicolumn{3}{|c|}{ - Copepod - } & \multicolumn{3}{|c|}{ - Nematode - } & \multicolumn{3}{|c|}{ - Temperature - } & \multirow{2}{*}{$\overline{\mathrm{df}}$} & \multicolumn{2}{|c|}{ Salinity } \\
\hline & $\mathrm{df}$ & $\mathrm{R}^{2}$ & $\mathrm{p}$ & $\mathrm{df}$ & $\mathrm{R}^{2}$ & $\mathrm{p}$ & $\mathrm{df}$ & $\mathrm{R}^{2}$ & $\mathrm{p}$ & $\mathrm{df}$ & $\mathrm{R}^{2}$ & $\mathrm{p}$ & & $\mathrm{R}^{2}$ & $\mathrm{p}$ \\
\hline Benthic chl a & - & - & - & 141 & -0.02 & 0.81 & 207 & 0.30 & $<0.005$ & 216 & 0.23 & $<0.005$ & 216 & 0.26 & $<0.005$ \\
\hline Copepods & 140 & -0.14 & 0.09 & - & - & - & 140 & -0.04 & 0.65 & 141 & -0.11 & 0.19 & 141 & 0.40 & $<0.005$ \\
\hline Nematodes & 206 & 0.25 & $<0.005$ & 139 & -0.08 & 0.36 & - & - & - & 207 & -0.04 & 0.58 & 207 & 0.27 & $<0.005$ \\
\hline Temperature & 215 & 0.23 & $<0.005$ & 140 & -0.13 & 0.12 & 206 & -0.05 & 0.51 & - & - & - & 216 & 0.02 & 0.75 \\
\hline
\end{tabular}




\section{Oxygen flux measurements}

An independent samples $t$-test analysis showed that there were no significant differences in dissolved oxygen fluxes between cores incubated at night and cores covered in black fabric but incubated during the day $(p<0.05, d f=6)$. There were no significant differences in oxygen fluxes between sites (Sites 1, 3 and 4) ( $p>0.05, \mathrm{df}=1)$. Oxygen fluxes were significantly higher under full sunlight in the dry than the wet season $(F=124, \mathrm{p}<0.01)$ (Fig. 4). There was also a significant difference in oxygen fluxes between the dry and wet seasons under dark conditions $(F=66.9, \mathrm{p}<0.01)$ (Fig. 4). Adjusted alpha values were used where the assumption of homogeneity of variance was violated. Based on the oxygen fluxes, production versus respiration ratios were calculated to be $48: 1$ in the dry season and 0.6:1 in the wet season.

\section{Salinity response experiment}

There were no significant differences in oxygen fluxes measured in any of the salinity treatments in either the light $(F=0.4, \mathrm{p}>0.05)$ or dark $(F=0.3, \mathrm{p}>$ 0.05). Mean oxygen flux measurements in the light were 4.1 (SD 0.6) and in the dark -1.1 (SD 0.2) mmol $\mathrm{O}_{2} \mathrm{~m}^{-2} \mathrm{~h}^{-1}$.

\section{Burial/salinity experiment}

Chl a concentrations were significantly higher in the 'no burial' treatment compared to the 'high burial' treatment $(\mathrm{p}<0.005)$, and there was no effect of 'low burial' (Fig. 5). Copepod density was significantly higher in the 'no burial' treatment compared to the 'low burial' treatment ( $\mathrm{p}<$ 0.005) and the 'high burial' treatment $(p<0.005)$ (Fig. 5). There were also significantly higher densities of copepods in the 'low burial' treatment compared to the 'high burial' treatment $(\mathrm{p}<0.005)$. Nematode density was significantly lower in the 'high burial' treatments compared to 'no burial' $(\mathrm{p}<0.005)$ and 'low burial' $(\mathrm{p}<$ 0.005). There was no interaction between burial and salinity for chl a

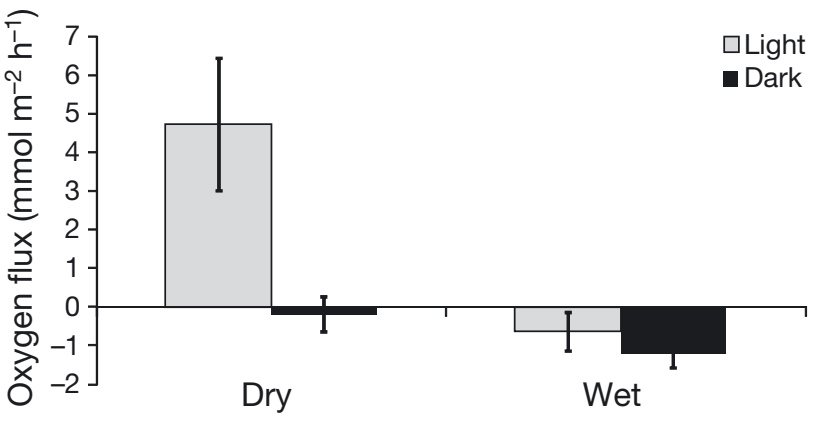

Fig. 4. Mean $( \pm \mathrm{SD})$ benthic oxygen fluxes $\left(\mathrm{mmol} \mathrm{O}_{2} \mathrm{~m}^{-2} \mathrm{~h}^{-1}\right)$ measured from intertidal mudflats in the dry and wet seasons under light (daytime) and dark (nighttime) conditions at Site 1 in the Norman River Estuary

$(F=1.2, \mathrm{p}=0.34)$ copepod density $(F=1.6, \mathrm{p}=0.23)$ or nematode density $(F=2.0, \mathrm{p}=0.16)$. There was no statistically significant difference in chl a concentrations between salinity treatments $(F=3.7, \mathrm{p}>0.05)$ after $7 \mathrm{~d}$. However, there were significantly fewer copepods $(F=95.5, \mathrm{p}<0.005)$ and nematodes $(F=$ $69.7, \mathrm{p}<0.005)$ in the freshwater treatment compared to the marine treatment. There was a statistically significant effect of burial on chl a concentrations $(F=9.0, \mathrm{p} \leq 0.005)$, copepod density $(F=209.2$, $\mathrm{p}<0.005)$ and nematode density $(F=55.7, \mathrm{p}<0.005)$.

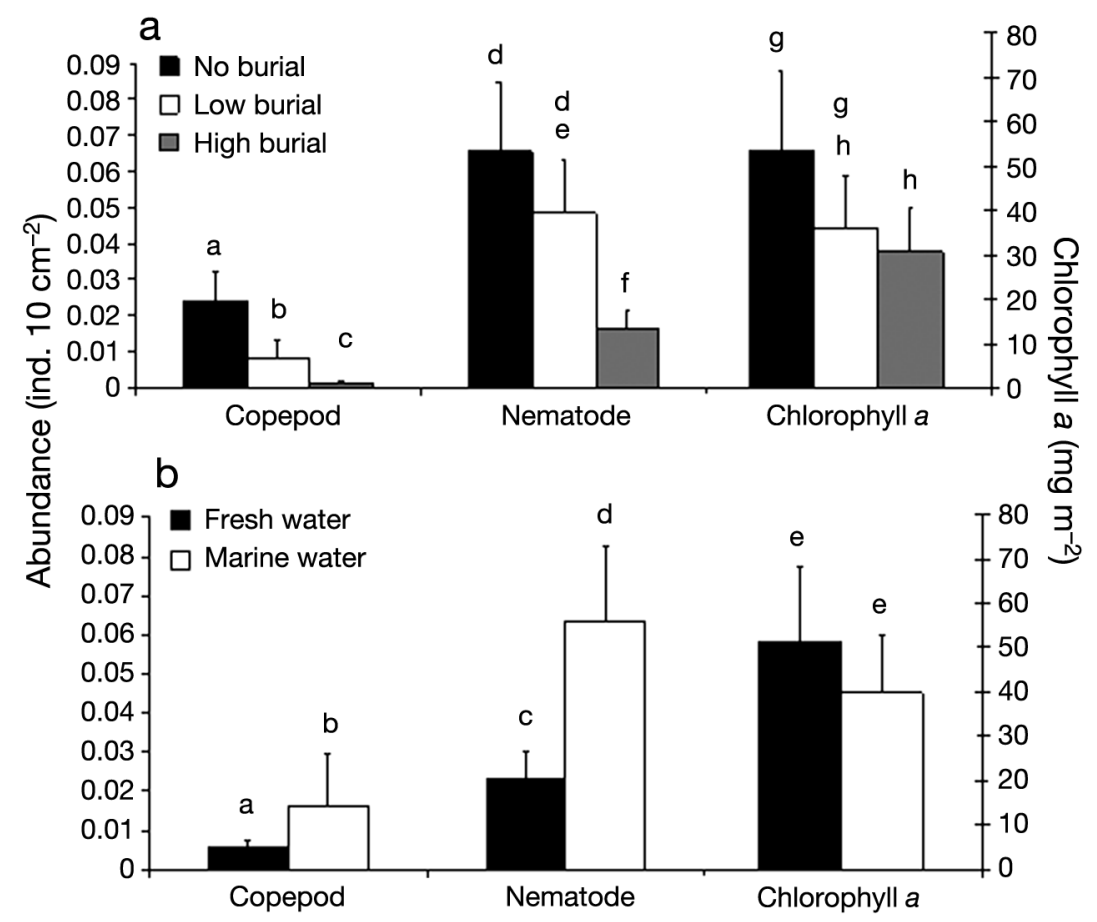

Fig. 5. Copepod density, nematode density and chlorophyll a concentrations measured from intertidal mudflat sediment in the dry season exposed to (a) levels of sediment burial (1 and $4 \mathrm{~cm}$ ), and (b) different salinities (fresh water and marine water) in controlled experiments. Different letters above bars indicate a significant difference $(p<0.05)$. Error bars are SD 


\section{DISCUSSION}

Compared to other tropical estuaries, biomass of MPB (and associated settled phytoplankton cells) in the Norman River Estuary was within the range of both tropical and wet-dry tropical estuaries (e.g. Alongi 1987, Montani et al. 2003, Pinckney et al. 2003, Nozais et al. 2005, Perissinotto et al. 2006, Burford et al. 2008). Even at the lower range of $\mathrm{chl} a$ concentrations found in the Norman River Estuary $\left(2.7 \mathrm{mg} \mathrm{m}^{-2}\right)$, concentrations are considered high compared to these other studies. For example, mean chl a concentrations in the Norman River Estuary were $42.2 \mathrm{mg} \mathrm{m}^{-2}$ (range $=2.7$ to 168.6), while the range of chl a concentrations in India found by Ansari et al. (2001) were 5.7 to $48.5 \mathrm{mg} \mathrm{m}^{-2}$. In tropical Australia, studies by Alongi (1987) measured concentrations from 1.8 to $8.9 \mathrm{mg} \mathrm{m}^{-2}$, and in Africa, concentrations were 1.4 to $480 \mathrm{mg} \mathrm{m}^{-2}$ (Nozais et al. 2005). Chlorophyll biomass on the mudflats in our study was approximately double the phytoplankton (Burford et al. 2012, Duggan 2012), on an areal basis, in the estuary. Therefore, the mudflats were likely to be significant contributors to the productivity of higher trophic levels.

In the dry season, the mudflats were net autotrophic, and C turnover was calculated to be approximately $1 \mathrm{~d}$ (Duggan 2012). Areal primary productivity was higher than that in a South African estuarine lake (van der Molen \& Perissinotto 2011) and a marsh tidal creek in the Gulf of Mexico (Cebrian et al. 2008), but lower than a tropical harbour in northern Australia which had a large mangrove forest area (Burford et al. 2008). The chlorophyll-specific primary productivity was also lower than the tropical harbour in Australia.

Meiofaunal abundance, on the other hand, was at the lower end of abundances found in other tropical estuaries, including those in the wet-dry tropics (Hodda \& Nicholas 1990, Alongi 1987, Ingole \& Parulekar 1988, Nicholas et al. 1992, Ansari et al. 2001, Pinckney et al. 2003, Nozais et al. 2005). For example, in the Norman River Estuary, mean nematode density was 9 ind. $10 \mathrm{~cm}^{-2}$ (range $=0$ to 82 ), whereas densities in other tropical Australian estuaries ranged from 3 to 987 ind. $10 \mathrm{~cm}^{-2}$ (Alongi 1987). In a temperate Australian estuary, densities were even higher, ranging from 180 to 1250 ind. $10 \mathrm{~cm}^{-2}$ (Nicholas et al. 1992) while in tropical Africa, densities were 149 to 4767 ind. $10 \mathrm{~cm}^{-2}$ (Pinckney et al. 2003). It is likely that the extremes in the seasonal hydrological regime in our study, i.e. larger flood magnitude (flow volume) making mudflat habitat unsuitable, combined with periods of no flow when nutrient availability would be low (Burford et al. 2012), contributed to these differences. Compared with MPB biomass estimates of $2167 \pm 1058 \mathrm{mg} \mathrm{C}$ $\mathrm{m}^{-2}$, meiofaunal biomass in our study was only $5.0 \pm$ $0.3 \mathrm{mg} \mathrm{C} \mathrm{m}^{-2}$ (Duggan 2012). This suggests that meiofauna were not limited by food availability, and that other factors were regulating their biomass.

We consider that reduced salinity in the Norman River Estuary and increased sediment mobility (sediment deposition, and potentially scouring) on intertidal mudflats during floods were the primary cause of reduced copepod and nematode densities in this period. Salinity was below 4 for approximately 2 to $3 \mathrm{mo}$, and our study showed that salinity correlated positively with both nematode and copepod densities. In manipulative experiments, both nematodes and copepods were at lower densities in the freshwater compared to the marine treatment. Salinity is one of the most important physical factors known to regulate meiofaunal density on intertidal mudflats in both temperate and tropical estuaries (Forster 1998, Moens \& Vincx 2000, Montagna et al. 2002). In wetdry tropical India, similar seasonal patterns of meiofaunal density were determined, with meiofaunal density decreasing quickly during monsoonal floods, and densities being positively correlated with salinity (Ingole \& Parulekar 1998, Ansari et al. 2001). High mortality rates of meiofauna associated with flood events have also been found in other monsooninfluenced systems (Ólafsson 1995, Nozais et al. 2005), as well as a temperate Australian estuary with a highly modified flow regime resulting in large episodic flood events (Nicholas et al. 1992). In all studies, low salinity was considered the primary cause of reductions in meiofaunal density during floods.

In addition to the effect of salinity, burial by sediment deposition during floods also impacted meiofaunal abundance. Visual examination of intertidal mudflat sediment during our study revealed deposition of fine-grained sediment transported downstream in flood waters during wet season flooding. Scouring was also observed once flooding reduced and mudflats were exposed once again, and is also likely to have removed meiofauna from mudflats. The amount and location of sediment deposition and/or scouring was not measured in this study for logistical reasons and was not a focus of this study. Sediment grain size is reported in the literature as a major regulator of meiofaunal densities, due to its role in determining the depth of the anoxic zone (Giere 2009). In fine mud (similar to that of the intertidal mudflats of our study), the anoxic zone is typi- 
cally found 2 to $3 \mathrm{~cm}$ below the sediment surface (Giere 2009). The anoxic zone limits the depth to which meiofauna can bury to escape unfavourable conditions, such as reduced salinity. Evidence of sediment movement (deposition and scouring) on intertidal mudflats was observed during both wet seasons in this study. Our experiments showed that meiofauna responded negatively to burial. Burial of meiofauna in $4 \mathrm{~cm}$ deep sediment significantly reduced both nematode and copepod density, and burial of meiofauna in $1 \mathrm{~cm}$ deep sediment significantly reduced copepod density. No meiofauna were found in the overlying sediment, suggesting meiofauna may have a limited ability to migrate to the surface in order to avoid the negative effects of falling oxygen levels within the sediment.

Along with a reduction in meiofaunal density, MPB biomass also decreased during floods in the Norman River Estuary, but not to the same extent. This was likely a result of prolonged reductions in salinity causing physiological stress, as well as increased sediment movement burying or removing MPB from intertidal mudflats. Consistent with the meiofaunal response, MPB biomass in our study was positively correlated with salinity. However, this contrasted a lack of reduction of MPB biomass exposed to fresh water for $7 \mathrm{~d}$ in the salinity experiment. In the shortterm study, benthic oxygen fluxes also remained unchanged when exposed to freshwater salinity for $23 \mathrm{~h}$. This suggests that at least in the short term, MPB on estuarine intertidal mudflats are able to withstand a sudden reduction in salinity from $\geq 35$ to 0 . Positive correlations between salinity and chl a have been found in numerous other studies, supporting the theory that estuarine MPB cannot withstand low salinity for long periods (Ansari et al. 2001, Perissinotto et al. 2006, Pillay \& Perissinotto 2009). The resilience of MBP to short-term low salinity may mean that in years of low wet season flow, any reduction in MPB biomass during floods may be minimal. This is supported by studies of other tropical Australian estuaries with lower flood intensities, where MPB biomass was relatively unchanged during flood events (Alongi 1994). Although the chl a concentrations varied between the wet and dry season, the proportion of algal groups (as measured by chl $b$ and chl $C$ concentrations) did not vary. Therefore, at the resolution of algal group, there was no obvious effect of salinity changes, although there may have been changes at a species level that would have gone undetected in our study.

Sampling for MPB was conducted at low tide in our study, so settled phytoplankton cells were also likely to be present on the mudflats. Our analytical methods precluded separation of the contribution of MPB and phytoplankton cells; however, both provide a food source for meiofauna. Additionally, studies of phytoplankton in the same system during the same time period by Burford et al. (2012) showed that phytoplankton biomass and productivity were also affected by flooding in both years. The study by Burford et al. (2012) showed that phytoplankton chl a concentrations were also relatively low throughout the year, typically less than $10 \mu \mathrm{g}^{-1}$, so the contribution to benthic chlorophyll measures is unlikely to be major.

In addition to, and in combination with, the effects of reduced salinity, movement of sediment (scouring and deposition) during increased freshwater flow can also impact the MPB community of intertidal mudflats through burial and/or removal of MPB biomass (Mitbavkar \& Anil 2006). Deposition of sediment transported downstream in flood waters was observed on the mudflats in our study, and burial in a sediment depth of $4 \mathrm{~cm}$ was shown experimentally to significantly reduce microphytobenthic biomass, with no significant impact of low levels of burial $(1 \mathrm{~cm})$, suggesting that these biota have some ability to withstand low levels of sediment deposition. This is consistent with the literature, which suggests MPB are able to migrate vertically within the sediment to take advantage of changing conditions (Pinckney et al. 2003, Kromkamp et al. 2006, Koh et al. 2007). MPB migration is often reported in the scale of $\mathrm{mm}$, which indicates that burial in a sediment depth of $4 \mathrm{~cm}$ may be beyond the range of their migration abilities.

Light availability is also known to be important in regulating MPB biomass and productivity in surface sediments of intertidal mudflats, with the depth to which light can penetrate the sediment largely determined by a combination of sediment type, the depth of water above the sediment and the turbidity of the water (Perissinotto et al. 2006). In our study, light availability did not vary greatly between seasons. However, as a result of the large volume of water flowing through the estuary during the wet season, intertidal mudflat exposure at low tide was absent or reduced during the 2 floods. The euphotic depth remained at approximately $0.9 \mathrm{~m}$ throughout the floods, so much of the mudflat would still have received some light (Burford et al. 2012). Therefore, although light availability was reduced, it was still sufficient for cell maintenance. Overall, the lack of exposure at low tide and the subsequent reduced light availability during wet season flooding, combined with reduced salinity and increased sediment 
movement through high flow rates, is likely to have contributed to the reduced MPB biomass. However, MPB biomass during wet season flooding was still relatively high compared to other systems (Alongi 1987, Montani et al. 2003, Pinckney et al. 2003, Nozais et al. 2005, Perissinotto et al. 2006, Burford et al. 2008). This may indicate a benthic algal community that is highly adapted to extended periods (i.e. months) of freshwater and low light availability. Although biomass during flooding was still relatively high, in the short-term study during minor flooding, benthic primary production was reduced, consistent with negative salinity effects and low light conditions. However, we acknowledge that primary production measurements were based on one sampling occasion. Consistent with the overall study, a wet season study of a wet-dry tropical estuary in India also found lower MPB biomass in the low intertidal zone than in the high intertidal zone, which was attributed to reduced light availability as a result of decreased tidal flat exposure (Mitbavkar \& Anil 2006).

Our study showed that freshwater flow in a wetdry tropical estuary had negative effects on MPB biomass and meiofaunal abundance during wet season flooding. Additionally, respiration increased and primary productivity decreased in a short-term study. However, post-flow there were positive effects on both biotic components, with MPB biomass in particular increasing substantially after flooding. Based on the study of 2 flood events (1 major, 1 minor), 3 distinct periods of response in the estuary are proposed: (1) a dry season where salinity was high (>30), tidal influences were strong, there was no downstream freshwater flow and MPB biomass and meiofaunal abundance were moderate. The dry season was followed by (2) a summer wet season where salinity was low $(<5)$, tidal influences were absent or reduced and large volumes of fresh water flowed through the estuary as a result of monsoonal rainfall. The wet season associated with the major flood lasted $3 \mathrm{mo}$ and with the minor flood, 2 mo. During both wet seasons, MPB biomass and meiofaunal abundance were significantly reduced. The final season was (3) a transitional period between the wet and the dry, where flooding was decreasing, salinity was consistently increasing (but still <30), and MPB biomass and meiofaunal abundance were high. The transitional period after both floods lasted for approximately 3 mo.

These flow regimes are consistent with the proposed wet season-dry season flow regimes of Eyre \& Ferguson (2006). In their study of biogeochemical processes and MPB biomass in a subtropical estuary, Eyre \& Ferguson (2006) proposed that there were 4 phases: the first, a flood peak where freshwater inflow is at its highest, salinity is reduced and internal biological processes were mostly eliminatedmuch like the wet season in the Norman River Estuary. The flood event was short and the estuary started to recover 2 to $3 \mathrm{~d}$ following the flood peak. The second phase was $1 \mathrm{wk}$ after the flood peak where MPB biomass was low, which was followed by an increase in MPB biomass in the third phase, $2 \mathrm{wk}$ after the flood peak, equivalent to the transitional period in the Norman River Estuary. A key distinction of the Norman River Estuary study was the 2 to 3 mo wet season, compared to the shorter flood of less than $1 \mathrm{wk}$ in the smaller, subtropical estuary studied by Eyre \& Ferguson (2006).

Our study has provided new insights into the response of benthic biota to the extreme hydrological variability characterising the wet-dry tropics. The transitional period between the wet and dry season was found to be an important recovery period in the estuary, where MPB biomass and meiofaunal abundance increased substantially after wet season flooding - and persisted for more than 6 mo after a major flood in the case of MPB biomass. This suggests that there may be a delayed positive response to the input of sediments and associated nutrients to the estuary during wet season flooding, and the duration of the response may be related to the scale of the flood. Further study is needed to determine if the scale of flooding subsequently affects the scale and timing of response, with larger floods likely to have a delayed positive response that persists for longer periods.

Acknowledgements. We thank G. Moore, D. Valdez, S. Faggotter \& A. Revill for field assistance, Raptis and Sons for access to their facilities, C. Polson and S. Knight for laboratory assistance, and R. Kenyon and P. Bayliss for advice. This project was part of the Tropical Rivers and Coastal Knowledge (TRaCK) program, and was funded through the Australian Government's Commonwealth Environment Research Facilities initiative; the Australian Government's Raising National Water Standards Program; Land and Water Australia; the Fisheries Research and Development Corporation and the Queensland Government's Smart State Innovation Fund.

\section{LITERATURE CITED}

Alber M (2002) A conceptual model of estuarine freshwater inflow management. Estuaries 25:1246-1261

Alongi DM (1987) Intertidal zonation and seasonality of meiobenthos in tropical mangrove estuaries. Mar Biol 95: $447-458$ 
Alongi DM (1994) Zonation and seasonality of benthic primary production and community respiration in tropical mangrove forests. Oecologia 98:320-327

Amiard-Triquet C, Rainbow PS (2009) Environmental assessment of estuarine ecosystems: a case study. CRC Press, Boca Raton, FL

Ansari A, Rivonkar CU, Sangodkar UMX (2001) Population fluctuation and vertical distribution of meiofauna in a tropical mudflat at Mandovi estuary, west coast of India. Indian J Mar Sci 30:237-245

Barros F, Hatje V, Figueiredo MB, Magalhães WF, Dórea HS, Emídio ES (2008) The structure of benthic macrofaunal assemblages and sediments characteristic of the Paguacu estuarine system, NE, Brazil. Estuar Coast Shelf Sci 78:753-762

Bunn SE, Arthington AH (2002) Basic principles and ecological consequences of altered flow regimes for aquatic biodiversity. Environ Manage 30:492-507

Burford MA, Alongi DM, McKinnon AD, Trott LA (2008) Primary production and nutrients in a tropical macrotidal estuary, Darwin Harbour, Australia. Estuar Coast Shelf Sci 79:440-448

Burford MA, Webster IT, Revill AT, Kenyon RA, Whittle M, Curwen G (2012) Controls on phytoplankton productivity in a wet-dry tropical estuary. Estuar Coast Shelf Sci 113:141-151

Cebrian J, Foster CD, Plutchak R, Sheehan KL and others (2008) The impact of Hurricane Ivan on the primary productivity and metabolism of marsh tidal creeks in the north central Gulf of Mexico. Aquat Ecol 42:1386-2588

Coull BC (1999) Role of meiofauna in estuarine soft-bottom habitats. Aust J Ecol 24:327-343

Duggan M (2012) Effect of river flow on downstream productivity in a tropical estuary. PhD dissertation, Griffith University, Nathan

> Dürr HH, Laruelle GG, van Kempen CM, Slomp CP, Meybeck M, Middelkoop H (2011) Worldwide typology of nearshore coastal systems: defining the estuarine filter of river inputs to the oceans. Estuar Coast 34:441-458

Elliott M, Whitfield AK (2011) Challenging paradigms in estuarine ecology and management. Estuar Coast Shelf Sci 94:306-314

Eyre BD, Ferguson AJP (2006) Impact of a flood event on benthic and pelagic coupling in a sub-tropical east Australian estuary (Brunswick). Estuar Coast Shelf Sci 66: 111-122

Forster SJ (1998) Osmotic stress tolerance and osmoregulation of intertidal and subtidal nematodes. J Exp Mar Biol Ecol 224:109-125

Giberto DA, Bremec CS, Cortelezzi A, Rodrigues Capitulo A, Brazeiro A (2007) Ecological boundaries in estuaries: macrobenthic $\beta$-diversity in the Río de la Plata system (34-36º $)$. J Mar Biol Assoc UK 87:377-381

Giere O (2009) Meiobenthology: the microscopic motile fauna of aquatic sediments, 2nd edn. Springer-Verlag, Berlin

Gillanders B, Kingsford M (2002) Impact of changes in flow of freshwater on estuarine and open coastal habitats and the associated organisms. Oceanogr Mar Biol Annu Rev 40:233-309

> Gillson J (2011) Freshwater flow and fisheries production in estuarine and coastal systems: where a drop of rain is not lost. Rev Fish Sci 19:168-186

Grego M, De Troch M, Forte J, Malej A (2009) Main meiofauna taxa as an indicator for assessing the spatial and seasonal impact of fish farming. Mar Pollut Bull 58: 1178-1186

Hodda M, Nicholas WL (1990) Production of meiofauna in an Australian estuary. Wetlands (Australia) 9:41-48

Ingole BS, Parulekar AH (1998) Role of salinity in structuring intertidal meiofaunal of a tropical estuarine beach: field evidence. Indian J Mar Sci 27:356-361

Jeffrey SW, Humphrey GF (1975) New spectrophotometric equations for determining chlorophylls $a_{1}, b_{1}, c_{1}$ and $c_{2}$ in higher plants, algae and natural phytoplankton. Biochem Physiol Pflanz 167:191-194

- Kennedy AD, Jacoby CA (1999) Biological indicators of marine environmental health: meiofauna - a neglected benthic component? Environ Monit Assess 54:47-68

Kennish MJ (1990) Ecology of estuaries Vol II: biological aspects. CRC Press, Boca Raton, FL

Kim H, Montagna PA (2009) Implications of Colorado River (Texas, USA) freshwater inflow to benthic ecosystem dynamics: a modelling study. Estuar Coast Shelf Sci 83: 491-504

Koh CH, Khim JS, Araki H, Yamanishi H, Koga K (2007) Within-day and seasonal patterns of microphytobenthos biomass determined by co-measurement of sediment and water column chlorophylls in the intertidal mudflat of Nanaura, Saga, Ariake Sea, Japan. Estuar Coast Shelf Sci 72:42-52

Kromkamp JC, Morris EP, Forster RM, Honeywill C, Hagerhey S, Paterson DM (2006) Relationship of intertidal surface sediment chlorophyll concentrations to hyperspectral reflections and chlorophyll fluorescence. Estuar Coast 29:183-196

Livingston RJ (1997) Trophic response of estuarine fishes to long-term changes of river runoff. Bull Mar Sci 60: 984-1004

> Loneragan NR, Bunn SE (1999) River flows and estuarine ecosystems: implications for coastal fisheries from a review and a case study of the Logan River, southeast Queensland. Aust J Ecol 24:431-440

Lorenzen CJ (1967) Determination of chlorophyll and pheopigments: spectro-photometric equations. Limnol Oceanogr 12:343-346

> MacIntyre HL, Geider RJ, Miller DC (1996) Microphyhtobenthos: the ecological role of the 'Secret Garden' of unvegetated, shallow-water marine habitats. I. Distribution, abundance and primary production. Estuaries 19(2A):186-201

Milliman JD, Farnsworth KL (2011) River discharge to the coastal ocean: a global synthesis. Cambridge University Press, New York, NY

Mitbavkar S, Anil AC (2006) Diatoms of the microphytobenthic community in a tropical intertidal sand flat influenced by monsoons: spatial and temporal variations. Mar Biol 148:693-709

> Moens T, Vincx M (2000) Temperature and salinity constraints on the life cycle of two brackish-water nematode species. J Exp Mar Biol Ecol 243:115-135

> Montagna PA, Kalke RD, Ritter C (2002) Effect of restored freshwater inflow on macrofauna and meiofauna in Upper Rincon Bayou, Texas, USA. Estuaries 25:1436-1447

Montani S, Magni P, Abe N (2003) Seasonal and interannual patterns of intertidal microphytobenthos in combination with laboratory and areal production estimates. Mar Ecol Prog Ser 249:79-91

> Moreno M, Ferrero TJ, Gallizia I, Vezzulli L, Albertelli G, Fabiano M (2008) An assessment of the spatial heterogeneity of environmental disturbance within an enclosed 
harbour through the analysis of meiofauna and nematode assemblages. Estuar Coast Shelf Sci 77:565-576

Nicholas WL, Bird AF, Beech TA, Steward AC (1992) The nematode faunal of the Murry River estuary, South Australia, the effects of the barrages across its mouth. Hydrobiologia 234:87-101

Nozais C, Perissinotto R, Tita G (2005) Seasonal dynamics of meiofauna in a South African temporarily open/closed estuary (Mdloti Estuary, Indian Ocean). Estuar Coast Shelf Sci 62:325-338

Ólafsson E (1995) Meiobenthos in mangrove areas in eastern Africa with emphasis on assemblage structure of free-living marine nematodes. Hydrobiologia 312:47-57

Peel MC, Finlayson BL, McMahon TA (2007) Updated world map of the Köppen-Geiger climate classification. Hydrol Earth Syst Sci 11:1633-1644

Perissinotto R, Iyer K, Nozais C (2006) Response of microphytobenthos to flow and trophic variation in two South African temporarily open/closed estuaries. Bot Mar 49: 10-22

Pillay D, Perissinotto R (2009) Community structure of epibenthic meiofauna in the St. Lucia Estuarine Lake (South Africa) during a drought phase. Estuar Coast Shelf Sci 81:94-104

Pinckney JL, Carman KR, Lumsden SE, Hymel SN (2003) Microalgal-meiofaunal trophic relationships in muddy intertidal estuarine sediments. Aquat Microb Ecol 31: 99-108

Pusey BJ (ed) (2011) National Land and Water Audit (2002). Aquatic biodiversity in northern Australia: patterns, threats and future. Charles Darwin University Press, Darwin

Editorial responsibility: Antony Underwood, Sydney, Australia
Remane A, Schlieper C (1971) Biology of brackish water. John Wiley \& Sons, New York, NY

Robins JB, Halliday IA, Staunton-Smith J, Mayer DG, Sellin MJ (2005) Freshwater-flow requirements of estuarine fisheries in tropical Australia: a review of the state of knowledge and application of a suggested approach. Mar Freshw Res 56:343-360

Santos PJP, Botter-Carvalho ML, do Nascimento-Júnior AB, Marinho RGC, Carvalho PVVC, Valença APMC (2009) Response of estuarine meiofauna assemblage to effects of fertilizer enrichment used in the sugar cane monoculture, Pernambuco, Brazil. Braz J Oceanogr 57:43-55

Sobrino I, Silva L, Bellido JM, Ramos F (2002) Rainfall, river discharges and sea temperature as factors affecting abundance of two coastal benthic cephalopod species in the Gulf of Cadiz (SW Spain). Bull Mar Sci 71:851-865

van der Molen JS, Perissinotto R (2011) Microalgal productivity in an estuarine lake during a drought cycle: the St. Lucia Estuary, South Africa. Estuar Coast Shelf Sci 92:1-9

Warfe DM, Pettit NE, Davies PM, Pusey BJ and others (2011) The 'wet-dry' in the wet-dry tropics drives river ecosystem structure and processes in northern Australia. Freshw Biol 56:2169-2195

> Wassenberg TJ, Hill BJ (1993) Diet and feeding behaviour of juvenile and adult banana prawns Penaeus merguiensis in the Gulf of Carpentaria, Australia. Mar Ecol Prog Ser 94:287-295

Whitfield AK, Elliott M, Basset A, Blaber SJM, West RJ (2012) Paradigms in estuarine ecology - a review of the Remane diagram with a suggested revised model for estuaries. Estuar Coast Shelf Sci 97:78-90

Submitted: February 6, 2013; Accepted: January 4, 2014 Proofs received from author(s): March 10, 2014 